\title{
Mesenteric Lymph Node
}

National Cancer Institute

\section{Source}

National Cancer Institute. Mesenteric Lymph Node. NCI Thesaurus. Code C77641.

A lymph node located in the mesentery. 